\title{
Relationships between Duration of Breastfeeding, Child Nutritional Status, and Development
}

\author{
Sri Rezki Wahdania Jamaluddin'), Andi Faradilah²), Rini Fitriani3)
}

1)Medical Study Program, Faculty of Medicine and Health Science, UIN Alauddin, Makassar, Indonesia 2)Nutrition Department, Faculty of Medicine and Health Science, UIN Alauddin, Makassar, Indonesia 3)Biomedic Department, Faculty of Medicine and Health Science, UIN Alauddin, Makassar, Indonesia

Background: Breast milk is one of the factors that can affect growth and development. WHO is promoted exclusive breastfeeding and also encourages mother to raise breastfeeding until the children reach 2 year of age. This study was aimed to examine the relationships between the duration of breastfeeding, child nutritional status and development.

Subjects and Method: This was an analytic observational study with a cross sectional design. The study was conducted in three health centers, in Makassar, South Sulawesi, Indonesia, from December 2019 to January 2020. A total of 200 mothers with children aged 1-3 years old were selected by purposive sampling. The dependent variables were child nutritional status and child development. The independent variable was duration of breastfeeding. Child development was measured using developmental pre-screening questionnaire. The other variables were collected by questionnaire. The relationships between variables were analyzed by Pearson correlation.

Results: Duration of breastfeeding was not associated with child nutritional status $(\mathrm{r}=$ 0.01; $\mathrm{p}=0.970$ ). Duration of breastfeeding increased child development, but it was statistically not significant $(\mathrm{r}=0.04 ; \mathrm{p}=0.550)$.

Conclusion: Duration of breastfeeding is not associated with child nutritional status. It increases child development, but it is statistically not significant.

Keywords: Breastfeeding, nutritional status, child development

\section{Correspondence:}

Andi Faradilah. Nutrition Department, Faculty of Medicine and Health Science, UIN Alauddin Makassar, Jl. Sultan Alauddin 36, Makassar, South Sulawesi, Indonesia. Email: a.faradilah@uin-alauddin.ac.id. Mobile: +6285242032134

\section{Cite this as:}

Jamaluddin SRW, Faradilah A, Fitriani R (2021). Relationships between Duration of Breastfeeding, Child Nutritional Status, and Development. J Matern Child Health. 06(02): 307-312. https://doi.org/10.26911/thejmch.2021.06.03.05.

\section{Journal of Maternal and Child Health is licensed under a Creative Commons}

Attribution-NonCommercial-ShareAlike 4.o International License.

\section{BACKGROUND}

Growth and development were two distinct but interrelated processes. Growth refers to physical changes, behavior, thoughts, feelings. Whereas development is changed regularly, for example, the child stands on one leg, tiptoes, climbs stairs, runs, and can be predicted as a result of maturity (Hurlock, 2010; Soetjiningsih, 2012).

Things that need to be considered in optimal child development are motor skills, language and speech communication, sen- sory social emotions, cognitive, creativity, morals, cooperation, spirituality and leadership (Suharjo, 2002; Hurlock, 2010)

The growth and development of children is influenced by several factors, one of which is nutrition. The best nutrition and play a role in growth and development can be fulfilled by giving breast milk. Pertiwi (2012) suggests that the growth and development of children aged 1-3 years is largely determined by the amount of breast milk they get. This is because breast milk 
contains antibodies, hormones, growth factors, anti-inflammatory and nutrition so it is good for children's growth and development and can reduce the risk of disease. Based on research in The Lancet Breastfeeding Series, it shows that breast milk plays a role in increasing intelligence and preventing obesity (Pertiwi, 2012).

WHO data (2014) shows that only $37 \%$ of children in the world do not receive exclusive breastfeeding (The World Health Organization, 2015). South Sulawesi Province shows that out of 163,595 children only 97,837 children or around $59.0 \%$ of children are exclusively breastfed (WHO, 2015). South Sulawesi Health Office data (2015) shows that exclusive breastfeeding in several districts has not reached the target set by the Ministry of Health, which is $80 \%$ and has not yet reached the target of WHO, where in 2025 the achievement of exclusive breastfeeding in the world will reach 50\%. Data on exclusive breastfeeding in each districts are Makassar 72.42\%, Takalar 56.75\%, Jeneponto 67.31\%, Barru $70.93 \%$, and Maros 79.77\%. Data on the health centers in Makassar are Sudiang 23.79\%, Bulukunyi (Takalar) 53.7\%, Bontomate'ne (Jeneponto) 79.0\%, Pujananting 60.0\%, and Mandai 58, 8\% (Suhud, 2013; Dinkes, 2015).

Exclusive breastfeeding affects the growth and development of children. Children who are given 80\% exclusive breastfeeding with normal nutritional status, while children who do not receive exclusive breastfeeding can be at risk of experiencing malnutrition (Giri, 2013; Indrasari, 2015; Rusjdi et al, 2015). In addition, information was obtained from the development of children who did not receive exclusive breastfeeding (Widayati, 2016; Nurlaila et al., 2017). Pratama (2013) and Zulaikha (2018) also shows that children who do not get breast milk are at a 9.5 times greater risk of experiencing developmental deviations compared to those who are breastfed. In addition, children who are breastfed have an IQ of 2.62 higher than those who are not breastfed (Pratama et al., 2013; Zulaikha, 2018). Therefore, giving ASI to children must be given optimally in order to support the growth and development of children so as to create a healthy and smart future generation (Hubertin, 2012).

Based on the description above, it is necessary to carry out further studies on the duration of breastfeeding with the growth and development of children. The purpose of this study was to analyze differences in growth and development of children aged 13 years based on the length of breastfeeding in order to increase public awareness of the importance of optimal breastfeeding to support children's growth and development so as to create a healthy and smart future generation.

\section{SUBJECTS AND METHOD}

\section{Study Design}

This was an analytic observational study with a cross sectional design. The study was carried out in three health centers in Makassar, South Sulawesi, Indonesia, from December 2019 to January 2020.

\section{Population and Sample}

The source population in this study were all children aged 12-36 months. A sample of 200 mothers with their children was carried out by purposive sampling.

\section{Study Variables}

The dependent variables were nutritional status and child development. The independent variable was duration of breastfeeding.

4. Operational Definition of Variables Duration of breastfeeding is the length of breastfeeding time.

Nutritional status is growth status of children aged 12-36 months measured by body weight and height and it adjusted to 
Jamaluddin et al./ Duration of Breastfeeding, Child Nutritional Status, and Development

children's anthropometric standard Indonesian Ministry of Health.

\section{Study Instruments}

Developmental pre-screening questionnaire was applied to assess child development. The other variables were collected by questionnaire.

\section{Data Analysis}

The relationships between variables were analyzed by Pearson correlation.

\section{Research Ethics}

This study was approved by the ethical committee of Medical and Health Ethic, Islamic State University of Alauddin with

Table 1. Characteristic Data of Subject

\begin{tabular}{|c|c|c|}
\hline+2 & $\mathbf{N}$ & $\%$ \\
\hline \multicolumn{3}{|l|}{ Gender of Children } \\
\hline Male & 103 & 51.5 \\
\hline Female & 97 & 48.5 \\
\hline \multicolumn{3}{|l|}{ Number of children } \\
\hline 1 -3 children & 187 & 93.5 \\
\hline$\geq 4$ children & 13 & 6.5 \\
\hline \multicolumn{3}{|l|}{ Age of Children } \\
\hline $12-24$ month & 93 & 46.5 \\
\hline $25-36$ month & 107 & 53.5 \\
\hline \multicolumn{3}{|l|}{ Sequence of children } \\
\hline $1-3$ & 186 & 93 \\
\hline$\geq 4$ & 14 & 7 \\
\hline \multicolumn{3}{|l|}{ Nutritional Status } \\
\hline Malnutrition & 16 & 8 \\
\hline Undernutrition & 37 & 18.5 \\
\hline Normal & 143 & 71.5 \\
\hline Overweight & 4 & 2 \\
\hline \multicolumn{3}{|l|}{ Family Income } \\
\hline$<1$ million & 125 & 62.5 \\
\hline 1-3 million & 22 & 11 \\
\hline$\geq 3$ million & 53 & 26.5 \\
\hline \multicolumn{3}{|l|}{ Duration of breastfeeding } \\
\hline$<6$ month & 28 & 14 \\
\hline 6-24 month & 140 & 70 \\
\hline$>24$ month & 32 & 16 \\
\hline \multicolumn{3}{|l|}{ Child development } \\
\hline Appropriate & 120 & 60 \\
\hline Deviate & 35 & 17.5 \\
\hline Dubious & 45 & 22.5 \\
\hline
\end{tabular}

Table 2. Association of Breastfeeding Duration and Nutritional Status

\begin{tabular}{lcc}
\hline \multirow{2}{*}{ Independent Variable } & \multicolumn{2}{c}{ Nutritional Status } \\
\cline { 2 - 3 } & $\mathbf{r}$ & $\mathbf{p}$ \\
\hline Breastfeeding Duration & -0.01 & 0.970 \\
\hline
\end{tabular}

number $\quad$ E.010/KEPK/FKIK/XII/2019 issued on December 18, 2019.

\section{RESULTS}

\section{Sample Characteristics}

The results of univariate analysis was described in Table 1. It showed that of 200 children, 70\% was breastfeed for 6-24 months, $71.5 \%$ had normal nutritional status, and 60\% had appropriate development. Interestingly, the majority of samples are classified as low income with less than 1 million per month. Half of sample were male (51.5\%) and aged 24-36 months (53.5\%). 
Jamaluddin et al./ Duration of Breastfeeding, Child Nutritional Status, and Development

Table 3. Association of Breastfeeding Duration and Child Development

\begin{tabular}{lcc}
\hline \multirow{2}{*}{ Independent Variable } & \multicolumn{2}{c}{ Child development } \\
\cline { 2 - 3 } & $\mathbf{r}$ & $\mathbf{p}$ \\
\hline Breastfeeding Duration & 0.04 & 0.550 \\
\hline
\end{tabular}

2. Bivariate Analysis

Bivariate analysis was performed using Kruskal Wallis test. The results of the bivariate analysis were depicted in Table 2 and Table 3 .

\begin{tabular}{cc}
\multicolumn{4}{c}{ DISCUSSION } \\
There was no significant association
\end{tabular}
between breastfeeding duration and nutritional status. Previous studies by Suhud (2013) and Ninuk et al. (2016) revealed similar result with the use of anthropometric parameter found no relationship between length of breastfeeding and growth and development of children (Elisa et al., 2014; Irot et al., 2017; Ningsih, 2021). Race, family, age, gender, genetic, stimulation, psychology, socio-economy, income, education, work, culture, physical condition, infection, and consumption of food or nutrition might contribute children's growth and development (Soetjiningsih, 2012; Tewu et al., 2017; Supariasa, 2019).

We were concerned with the complementary feeding issue, as subjects included in this study entered the age of complementary feeding. Complementary feeding in this case is associated with energy intake and protein intake that children get after they are more than 6 months old (Ninuk et al, 2016; Diniyyah, 2017; Rahim, 2017). As previously mentioned by Muchlis et al. (2013) and Diniyyah (2017) found that carbohydrate, protein and fat intakes of children influenced their nutritional status. In this study, we did not collect food intake data as complementary feeding of subjects therefore we could not elaborate more to the result of our anthropometric data. Rational to assume that there was the effect of complementary feeding to influence weight and height of children. After period of exclusive breastfeeding, children will start complementary feeding phase and insufficiency of children's energy intake at that phase will affect delay of children's growth (Muchlis, 2011; Soetjiningsih, 2012; Horta, Mola et al., 2015; Diniyyah et al., 2017).

Child development (KPSP scores) showed the difference between group. Approporiate group (60\%) is higher than other groups. Nineteen months was found to be the best length of breastfeeding duration in regards to having normal development of children. Sari et al. (2015) and Lestari et al. (2017), showed that there were a relationship between breastfeeding and child development (Sari et al., 2015; Lestari et al., 2017; Kumala et al., 2019).

Study by Fitri et al. (2014) reported exclusively breastfed children have 5.47 times probability of increased development compared to non-exclusively breastfed children. In addition, children who were exclusively breastfed for 6 months or more had higher ASQ (Ages and Stages Questionnaire) scores (gross motor skills) than children who were not exclusively breastfed (Ali et al., 2014). This is because breast milk contains many food juices that can accelerate nerve development and brain cell growth and currently, there is no food or formula that can match the nutritional content of breast milk (Elyas et al., 2017). Moreover, Pramata (2013) revealed breastfed children have 9.5 times lower risk of abnormal development compared to non breastfed children(Pratama et al., 2013). Bounding attachment during breastfeeding 
Jamaluddin et al./ Duration of Breastfeeding, Child Nutritional Status, and Development

time between mother and children will provide stimuli through eye contact, hug, and communication that will affect children development (Diah, 2012; Nurjanah, 2018).

In this study, we took a range of age subjects from 12 to 36 months. With the wider range of age, we explore not only the period of exclusive breastfeeding but also the 1000 days golden period of children's early life. Limitation of this study including no assessment of complementary feeding that needed to calculate for showing association on nutritional status. Moreover, the duration of each breastfeeding time probably will also influence the bonding between mother and children that later develops. Unfortunately we did not measure the length of each breastfeeding duration.

This study added new evidence of breastfeeding benefit to the children's development. More specifically, extending the duration of breastfeeding to more than 6 months as exclusive breastfeeding will aid the development of children.

\section{AUTHOR CONTRIBUTION}

Sri Rezki Wahdania Jamaluddin collected data, interpreted KPSP, analized data, and wrote the manucript. Andi Faradilah developed the idea of the study, drafted the manuscript and gave feedback. Rini Fitriani gave feedback to manuscript. All the authors approved the manuscript.

\section{CONFLICT OF INTEREST}

The authors declare that the study was conducted in the absence of any commercial or financial relationships that could be construed as a potential conflict of interest.

\section{FUNDING AND SPONSORSHIP}

None.

\section{ACKNOWLEDGEMENT}

There was no external fund.
REFERENCE

Ali SS, Dhaded SM, Goudar SS (2014). The impact of nutrition on child development at 3 years in a rural community of India. Int J Prev Med. 5(4): 494-9.

Andriani R, Wismaningsih ER, Indrasari, OR (2015). Hubungan pemberian asi eksklusif dengan kejadian status gizi kurang pada balita umur 1-5 tahun. Jurnal Wiyata. 2 (1): 44-47.

Hurlock E (2010). Psikologi perkembangan suatu pendekatan sepanjang rentang kehidupan, psikologi perkembangan. Jakarta: Erlangga.

Diah (2012). Manfaat Asi eksklusif, perkembangan anak. Jakarta: EGC.

Diniyyah SR, Nindya TS (2017). Asupan energi, protein dan lemak dengan kejadian gizi kurang pada balita usia 24-59 bulan di Desa Suci, Gresik. Amerta Nutr. 1(4): 341-350. doi: 10.20473/Amnt.V1i4.7139.

Dinkes (2015). Profil kesehatan provinsi Sulawesi Selatan Tahun 2015.

Elisa AP, Nova H, Kapantow NM (2014). Faktor risiko underweight balita umur 7-59 bulan. Jurnal Kesehatan Masyarakat. 9(2): 115-121. doi: 10.15294/Kemas.V9i2.2838.

Elyas L, Mekasha A, Admasie A, Assefa E (2017). Exclusive breastfeeding practice and associated factors among mothers attending private pediatric and child clinics, Addis Ababa, Ethiopia: a cross-sectional study. Int $\mathrm{J}$ Pediatr. 2017: 8546192. https://doi.org/10.1155/2017/8546192.

Fitri DI, Chundrayetti E, Semiarty R (2014). Hubungan pemberian asi dengan tumbuh kembang bayi umur 6 bulan di Puskesmas Nanggalo. Jurnal Kesehatan Andalas. 3(2): 136-40. doi: 10.25077/Jka.V3i2.51.

Horta BL, Mola LDC, Victora CG (2015). Breastfeeding and intelligence: a 
Jamaluddin et al./ Duration of Breastfeeding, Child Nutritional Status, and Development

systematic review and meta-analysis. Acta Paediatr. 104(467): 3-13. doi: 10.1111/Apa.13139.

Hubertin SP (2012). Konsep penerapan asi eksklusif. Jakarta: EGC.

Irot RA, Kapantow NH, Punuh MI (2017). Hubungan antara pemberian ASI eksklusif dengan status gizi bayi usia 6-12 bulan di wilayah kerja puskesmas Walantakan Kecamatan Langowan Utara Kabupaten Minahasa. Kesmas. 6(3): $1-9$.

Kementerian Kesehatan RI Badan Penelitian Dan Pengembangan (2018). Hasil utama riset kesehatan dasar, Kementrian Kesehatan Republik Indonesia.

Kumala H, Purnomo W (2019). Hubungan asi eksklusif dengan perkembangan balita yang memiliki riwayat berat badan lahir rendah (bblr) di Puskesmas Tanah Kali Kedinding Surabaya. Media Gizi \& Kesehatan Masyarakat. 8(2): 33-39. doi: http://dx.doi.org/10.20473/mgk.v8i2.2019.33-39.

Giri KWM (2013). Hubungan pemberian asi eksklusif dengan status gizi balita usia 6-24 bulan di Kampung Kajanan, Buleleng. JST. 2(1) : 184-192. doi: 10.23887/Jst-Undiksha.V1i1.1423.

Lestari S, Trisnowati T (2017). Pengaruh riwayat pemberian asi terhadap perkembangan anak usia prasekolah di TK Kristen Imanuel Surakarta. Indonesian Journal On Medical Science. 4(1): 88-95. Available At: Http://Ejo-

urnal.Ijmsbm.Org/Index.Php/Ijms/A rticle/View/101.

Muchlis N, Veni H, Nurhaedar J(2011). Hubungan asupan energy dan protein dengan status gizi balita Di Kelurahan Tamamaung. Program Studi Ilmu Gizi FKM UNHAS.
Kesuma N, Jurnalis AYD, Rusjdi SR (2015). Hubungan status gizi bayi dengan pemberian asi eksklusif, tingkat pendidikan ibu dan status ekonomi keluarga di Wilayah Kerja Puskesmas Padang Pasir. Jurnal Kesehatan Andalas. 4(1): 37-44. doi: 10.25077/Jka.V4i1.184.

Ningsih SR, Faradilah A, Rahim R (2021). Hubungan praktik menyusui dengan status gizi dan skor kuisoner pra skrining perkembangan (KPSP) pada Anak usia 1 - 3 Tahun. 4(1): 65-74. http://jurnal.fkmumi.ac.id/index.php /woh/article/view/woh4107.

Hartini NS, Susanto T, Susanto N (2016). Hubungan pemberian ASI dengan status gizi balita usia 6-23 bulan di Kelurahan Klitren Gondokusuman Yogyakarta tahun 2016. Jurnal Medika Respati. 11(3): 42-53. doi:https://doi.org/10.35842/mr.v11i3.2 7.

Nurjanah S (2018). Asi eksklusif meningkatkan perkembangan bayi usia 6-12 bulan di wilayah kerja Puskesmas Banyu Urip Surabaya. J Health Sci. 8(2): 221-8. https://doi.org/10.33086/jhs.v8i2.209.

Nurlaila N, Riyatun K, Iswati N (2017). Hubungan pemberian asi eksklusif dengan perkembangan motorik pada bayi. Jurnal Ilmiah Kesehatan Keperawatan. 13(2): 78-83. https://doi.org/10.26753/jikk.v13i2.213.

Pertiwi P (2012). Factors that influence exclusive breastfeeding at Kelurahan Kunciran Indah Tangerang. Jakarta: Universitas Indonesia.

Pratama AM, Budiati T (2013). Perkembangan bayi yang diberikan asi eksklusif dan tidak eksklusif. Jakarta: Universitas Indonesia.

Purba EA, Kapantow NH, Momongan N (2017). Hubungan antara pemberian 
asi eksklusif dengan status gizi bayi 612 bulan di wilayah kerja Puskesmas Tatelu Kecamatan Dimembe Kabupaten Minahasa Utara. KESMAS. 6(4). https://ejournal.unsrat.ac.id/index.php/kesmas/article/view/23102.

Sari OP, Nugraheni SA, Rahfiludin MZ (2015). Hubungan Pemberian asi eksklusif dengan perkembangan bayi usia o-6 bulan di wilayah kerja Puskesmas Padangsari Kota Semarang. Jurnal Kesehatan Masyarakat (Undip). 3(1): 271-277. http://ejournal-s1.undip.ac.id/index.php/jkm.

Soetjiningsih (2012). ASI petunjuk untuk tenaga kerja kesehatan. Jakarta: EGC.

Suhud C (2013). Hubungan pemberian asi eksklusif dengan tumbuh kembang anak usia toddler di wilayah kerja Puskesmas Tamangapa Antang Makassar. Thesis. UIN Alauddin: Fakultas Kedokteran dan Ilmu Kesehatan. http://repositori.uin-alauddin.ac.id/id/eprint/3035.

Supariasa, Penilaian Status Gizi, JBKE (2019). Penilaian status gizi. Jakarta: EGC.

Tewu I, Punuh MI Purba RB (2017). Hu- bungan antara pemberian asi eksklusif dengan status gizi bayi usia 6-12 bulan di wilayah kerja Puskesmas Raanan Baru Kecamatan Motoling Barat. Jurnal Kesehatan Masyarakat Unsrat. 6(3).

World Health Organization (2015). The World Health Organization's Infant Feeding Recommendation, WHO.

Widayati W (2016). Hubungan Pemberian asi terhadap perkembangan bayi usia 6-12 bulan. Jurnal Ilmiah Kesehatan, 5(9). 614-620. doi: 10.35952/Jik.V5i9.24 .

Zulaikha F, Rizqi NFS (2018). Hubungan pemberian ASI eksklusif dengan perkembangan bahasa anak usia prasekolah di PAUD wilayah kerja puskesmas Mangkupalas Samarinda tahun 2017 (The relationship of giving exclusive breastfeeding with language development of pre-school children in paud in the region of Puskesmas Mangkupalas in 2017). Jurnal Ilmu Kesehatan. 6(1): 18-25. https://journals.umkt.ac.id/index.php/jik/article /view/93/54. 